\title{
Treatment administered to newborns with congenital syphilis during a penicillin shortage in 2015, Fortaleza, Brazil
}

\author{
Ana Fátima Braga Rocha ${ }^{{ }^{*}}$ (D), Maria Alix Leite Araújo ${ }^{1}$, Melanie M. Taylor ${ }^{2,3}$, Edna O. Kara ${ }^{2}$ and
} Nathalie Jeanne Nicole Broutet ${ }^{2}$

\begin{abstract}
Background: Between 2014 and 2016, Brazil experienced a severe shortage in penicillin supply, resulting in a lack of treatment among some pregnant women and newborns with syphilis and the use of non-evidence-based regimens. This study evaluated all live births in Fortaleza reported with CS in 2015 in order to identify the different therapeutic regimens used in newborns during this period of penicillin shortage.

Methods: A retrospective cross-sectional study design was conducted using manually extracted data from medical chart review of maternal and infant cases delivered in 2015 from all public maternity hospitals in the city of Fortaleza. Data collection occurred from June 2017 to July 2018.

Results: A total of 575 congenital syphilis cases were reported to the municipality of Fortaleza during 2015 and 469 (81.5\%) were analyzed. Of these, only 210 (44.8\%) were treated with a nationally-recommended treatment. As alternative therapeutic options, ceftriaxone was used in 65 (13.8\%), Cefazolin in 15 (3.2\%) and the combination of more than one drug in 179 (38.2\%). Newborns with serum VDRL titers $\geq 1: 16(p=0.021)$, who had some clinical manifestation at birth $(p=0.003)$, who were born premature $(p<0.001)$, with low birth weight $(p=0.010)$, with jaundice indicative of the need for phototherapy $(p=0.019)$ and with hepatomegaly $(p=0.045)$ were more likely to be treated with penicillin according to national treatment guidelines compared to newborns treated with other regimens.

Conclusion: During the period of shortage of penicillin in Fortaleza, less than half of the infants reported with CS were treated with a nationally-recommended regimen, the remaining received treatment with medications available in the hospital of birth including drugs that are not part of nationally or internationally-recommended treatment recommendations.
\end{abstract}

Keywords: Penicillin, Syphilis, Congenital syphilis, Shortage, Treatment

\footnotetext{
*Correspondence: ana_lumen@hotmail.com

The views expressed in this paper are those of the authors and do not necessarily represent the position of the World Health Organization, the U.S. Centers for Disease Control and Prevention, or other organizations.

'University of Fortaleza-UNIFOR, Av. Washington Soares, 1321, Edson Queiroz, Fortaleza, Ceará CEP 60.811-905, Brazil

Full list of author information is available at the end of the article
}

C C The Author(s). 2021 Open Access This article is licensed under a Creative Commons Attribution 4.0 International License, which permits use, sharing, adaptation, distribution and reproduction in any medium or format, as long as you give appropriate credit to the original author(s) and the source, provide a link to the Creative Commons licence, and indicate if changes were made. The images or other third party material in this article are included in the article's Creative Commons licence, unless indicated otherwise in a credit line to the material. If material is not included in the article's Creative Commons licence and your intended use is not permitted by statutory regulation or exceeds the permitted use, you will need to obtain permission directly from the copyright holder. To view a copy of this licence, visit http://creativecommons.org/licenses/by/4.0/. The Creative Commons Public Domain Dedication waiver (http://creativecommons.org/publicdomain/zero/1.0/) applies to the data made available in this article, unless otherwise stated in a credit line to the data. 


\section{Background}

Global estimates from the World Health Organization (WHO) showed that, in 2016, approximately 1 million pregnant women were infected with syphilis resulting in over 600,000 congenital syphilis (CS) cases of which 355, 000 were adverse birth outcomes including 200,000 stillbirths and neonatal deaths [1]. In 2015, more than 22,800 cases of CS were recorded in countries in Latin America and the Caribbean, corresponding to an incidence rate of 1.7 cases per thousand live births. This rate is mainly related to the cases reported by Brazil, which corresponded to $85 \%$ of the records in this region [2].

In Brazil, CS is a mandatory reporting event and recent epidemiological data indicate an incidence rate of 9.0 cases per thousand live births, with the Northeast Region presenting 9.6 cases per thousand live births [3]. These rates are much higher than the elimination threshold established by the WHO, which is less than 0.5 cases for every thousand live births [4] showing that effective prevention measures in general and high-risk populations in Brazil need to be implemented for this goal to be achieved.

Between 2014 and 2016, Brazil, along with 38 other countries, experienced a serious penicillin supply shortage due to manufacturing interruptions and quality assurance issues, resulting in lack of correct treatment among some pregnant women and infants with syphilis and use of non-evidence-based regimens [5]. The Ministry of Health $(\mathrm{MoH})$ recommended the prioritization of benzathine penicillin for the treatment of pregnant women with syphilis and crystalline penicillin for infants with CS. The MoH did not recommend alternative treatment regimens for treatment of syphilis among pregnant women when penicillin was not available. The alternative treatment regimen recommended for infants during the period of penicillin shortages included ceftriaxone 25 to $50 \mathrm{mg} / \mathrm{kg}$, once a day, intravenously or intramuscularly for 10 to 14 days [6]. These alternative treatments for infants were proposed without scientific evidence demonstrating their effectiveness [6].

Fortaleza, State of Ceará, Northeast Brazil has a population of approximately 2.5 million inhabitants, and ten public maternity hospitals. These maternities attend an average of 39,000 births a year and are responsible for 99.4\% of the municipality's CS notifications. Health care is offered through the Unified Health System (SUS), which has a network of services with different levels of complexity. Maternal syphilis rates are high in Fortaleza and CS is a serious problem with detection rate of 23.1 cases per thousand live births [7], much higher than the national incidence rate [3]. During 2014-2016, antenatal care clinics and obstetrics units in Fortaleza experienced different shortage scenarios varying from total stockout to insufficient quantity of penicillin formulations (benzathine, procaine, crystalline) to supply the demand for treatment of pregnant women and newborns. This study evaluated all live births in Fortaleza reported with CS in 2015 in order to identify the different therapeutic regimens used in newborns reported with CS during the period of penicillin shortage.

\section{Methods}

A retrospective cross-sectional study design was conducted using manually extracted data from medical chart review of maternal and infant cases delivered in 2015 from all public maternity hospitals in the city of Fortaleza.

The Brazilian $\mathrm{MoH}$ CS definition was used as follows [8]:

- Live born infant whose mother presented, during prenatal care or at the time of delivery, with a reactive non-treponemal test with any titration and reactive treponemal test, and who was not treated or received inadequate treatment.

- Live born infant whose mother was not diagnosed with syphilis during pregnancy, and when it is impossible to perform the treponemal test at the maternity, has a reactive non-treponemal test of any titration at the time of delivery.

- Live born infant whose mother was not diagnosed with syphilis during pregnancy, and when it is impossible to perform the non-treponemal test at the maternity, has a reactive treponemal test at the time of delivery.

- Live born infant whose mother has a reactive treponemal test and a non-treponemal non-reactive test at the time of delivery, without prior treatment.

According to Brazil MOH guidelines in 2015, maternal syphilis treatment is considered inadequate when a treatment other than benzathine penicillin $G$ is used; when the benzathine penicillin $G$ is not administered according to the clinical stage of the infection; when it is not started up to 30 days before delivery; and/or when the partner has untreated syphilis [8].

The medication recommended for use in the treatment of infants or children with CS is penicillin (crystalline, procaine or benzathine). Need for treatment is based on the maternal treatment during pregnancy, the titration of the newborn's non-treponemal test compared to the maternal, and the newborn's clinical findings and laboratory tests as follows [8]:

1) Newborns without clinical signs of CS at birth with a non-reactive serum VDRL, should receive benzathine penicillin $\mathrm{G}$, a single dose of $50,000 \mathrm{IU} / \mathrm{kg}$ intramuscularly. 
2) Newborns with abnormal cerebrospinal fluid (CSF) (reactive CSF VDRL, elevated protein) should receive aqueous crystalline penicillin G 50,000 IU/ $\mathrm{kg} /$ dose, intravenously, every $12 \mathrm{~h}$ (in the first 7 days of life) and every $8 \mathrm{~h}$ (after 7 days of life), for 10 days.

3) Newborns with clinical evidence of congenital syphilis and/or reactive serum VDRL, and/or abnormal long bone $\mathrm{x}$-rays and/or changes in the complete blood count should receive aqueous crystalline penicillin G 50,000 IU/kg/dose, intravenously, every $12 \mathrm{~h}$ (in the first 7 days of life) and every $8 \mathrm{~h}$ (after 7 days of life), for 10 days; or procaine penicillin G 50,000 IU/kg, single daily dose, intramuscularly for 10 days.

Data collection occurred from June 2017 to July 2018. CS case notification forms and hospital medical records were reviewed to collect information on infant treatment. When there were inconsistencies between the records, the data in the medical record was used.

Cases of newborns who died, non-residents in the city of Fortaleza and infant cases whose medical records were not found were excluded. Infants who died were excluded, due to deaths occurring very early (up to 4 days of life), thus treatment regimens could not be adequately accessed. The exclusion of those who did not live in Fortaleza was due to the fact that data from this study were part of a broad project that also intends to collect data on the follow-up of these children for future analysis and publication. The infants who do not live in Fortaleza are followed in their municipalities, which would make access to this data impossible.

Cases who had co-infection with HIV, hepatitis B and $\mathrm{C}$, toxoplasmosis, rubella, cytomegalovirus, congenital herpes virus or zika virus were also excluded due to the possibility of interference in the evaluation of the clinical manifestations and laboratory findings of CS.

The variables analyzed were: timing of mother's diagnosis, mother's treatment during prenatal care, gestational age at delivery, baby's weight at birth, performance and result of the non-treponemal test (VDRL) of peripheral blood and CSF, presence of CSF abnormalities, radiological examination of long bones, changes in the complete blood count, presence of clinical manifestations of CS at birth, and treatment regimen administered to the newborn.

The nationally-recommended treatment scheme for CS comprised any of the three options: 1) aqueous crystalline penicillin $\mathrm{G} \mathrm{50,000} \mathrm{IU/kg/dose,} \mathrm{intravenously,}$ every $12 \mathrm{~h}$ (in the first 7 days of life) and every $8 \mathrm{~h}$ (after 7 days of life), for 10 days; 2) procaine penicillin G 50 , $000 \mathrm{IU} / \mathrm{kg}$, single daily dose, intramuscularly for 10 days; 3) benzathine penicillin $\mathrm{G}$, a single dose of $50,000 \mathrm{IU} / \mathrm{kg}$ intramuscularly. Treatments that followed the national guideline regimens for CS, including clinical and laboratorial parameters of mothers and infants, were considered adequate [8]. Only antibiotics administered to the newborns for the treatment of CS were reviewed, those used for other pathologies were not considered.

Newborn exams were considered abnormal based on the following parameters: CSF- reactive VDRL, protein content $>150 \mathrm{mg} / \mathrm{dL}$ and/or leukocytes $>25$ cells $/ \mathrm{mm} 3$; Radiography of long bones - presence of involvement in the metaphysis or diaphysis or findings consistent with periostitis, osteitis or osteochondritis; Complete blood count - anemia (hemoglobin - 1 to 3 days of life: $<14.5 \mathrm{~g} /$ $\mathrm{dL}, 7$ days of life: $<13.5 \mathrm{~g} / \mathrm{dL})$, thrombocytopenia $(<150$, $000 / \mathrm{mm} 3$ ), leukocytosis and leukopenia (reference values for leukocytes: up to 1 day of life: 9000 to $30,000 / \mathrm{mm} 3,2$ to 7 days of life: 5000 to $21,000 / \mathrm{mm} 3$; reference values for neutrophils: up to 1 day of life: 6000 to $26,000 / \mathrm{mm} 3,2$ to 7 days of life: 1500 to $10,000 / \mathrm{mm} 3)[8,9]$.

Clinical manifestations at birth were those related to early CS: prematurity (birth with gestational age less than 37 weeks), low birth weight $(<2500 \mathrm{~g})$, hepatomegaly, splenomegaly, skin lesions, jaundice consistent with need for phototherapy and pseudoparalysis of the limbs [8].

The data were analyzed using the statistical software SPSS (Statistical Package for the Social Sciences) version 22. A descriptive analysis was performed using the frequency distribution for the categorical variables and bivariate analysis that applied Pearson's $x^{2}$ test and Fisher's exact test, establishing a 5\% significance level and a $95 \%$ confidence interval.

This study was approved by the Research Ethics Committee of the University of Fortaleza (UNIFOR) with opinion number 2.110.189.

\section{Results}

In 2015, there were 575 live births reported with CS in Fortaleza. Of these, 106 (18.4\%) cases were excluded from the analysis: nine cases of neonatal death, 26 not residing in Fortaleza, 43 whose medical records were not available and 28 which had co-infection. Records from the remaining 469 newborns were analyzed.

Data on the mothers of these newborns revealed that $390(83.1 \%)$ received prenatal care and of these, 264 (67.7\%) were diagnosed with syphilis during prenatal care; 79 (16.9\%) women did not receive prenatal care and were diagnosed with syphilis at the time of delivery. All women were considered inadequately treated or did not undergo treatment (Table 1).

The result of the newborn's serum VDRL test was reactive in $367(78.6 \%)$ and for $53(14.4 \%)$ the titration was $\geq 1$ : 16. A total of 26 (8.9\%), 10 (7.2\%) and 159 (43.9\%) infants had alterations at the CSF exam, in the long-bone radiography and in the blood count (anemia, thrombocytopenia, leukocytosis or leukopenia), respectively. Four hundred 
Table 1 Maternal treatment, performed tests and clinical manifestations in cases of CS. Fortaleza, Ceará, 2015. $(n=469)$

\begin{tabular}{|c|c|c|}
\hline Variables & Number & Percent \\
\hline \multicolumn{3}{|l|}{ Maternal } \\
\hline Mother did not attend prenatal care & 79 & 16.9 \\
\hline Mother attended prenatal care & 390 & 83.1 \\
\hline Mother not diagnosed with syphilis in prenatal care & 126 & 32.3 \\
\hline Mother diagnosed with syphilis in prenatal care & 264 & 67.7 \\
\hline \multicolumn{3}{|l|}{ Maternal treatment in prenatal care } \\
\hline Inadequate treatment & 204 & 77.3 \\
\hline Untreated & 60 & 22.7 \\
\hline \multicolumn{3}{|l|}{ Newborn } \\
\hline Newborns with reactive serum VDRL result at birth $(n=467)^{\mathrm{a}}$ & 367 & 78.6 \\
\hline Newborns with serum VDRL titration at birth $\geq 1: 16 \quad(n=367)$ & 53 & 14.4 \\
\hline Alteration in long bone radiography $(n=139)^{\mathrm{a}}$ & 10 & 7.2 \\
\hline CSF alteration $(n=292)^{\mathrm{a}}$ & 26 & 8.9 \\
\hline \multicolumn{3}{|l|}{ Type of CSF alteration $(n=26)^{b}$} \\
\hline Reactive CSF VDRL test & 8 & 30.8 \\
\hline Proteins $>150 \mathrm{mg} / \mathrm{dL}$ & 11 & 42.3 \\
\hline Leukocytes $>25$ cells $/ \mathrm{mm}^{3}$ & 10 & 38.4 \\
\hline Blood count alteration $(n=362)^{a}$ & 159 & 43.9 \\
\hline \multicolumn{3}{|l|}{ Type of Blood count alteration $(n=159)^{b}$} \\
\hline Anemia & 43 & 27.0 \\
\hline Thrombocytopenia & 31 & 19.5 \\
\hline Leukocytosis & 83 & 52.2 \\
\hline Leukopenia & 27 & 17.0 \\
\hline Showed some clinical manifestation $(n=456)$ & 199 & 43.6 \\
\hline \multicolumn{3}{|l|}{ Type of clinical manifestation $(n=199)^{b}$} \\
\hline Jaundice level requiring phototherapy & 116 & 58.3 \\
\hline Low birth weight & 87 & 43.7 \\
\hline Preterm birth & 65 & 32.6 \\
\hline Hepatomegaly & 14 & 7.0 \\
\hline Skin lesions & 10 & 5.0 \\
\hline Splenomegaly & 8 & 4.0 \\
\hline Limb pseudoparalysis & 1 & 0.5 \\
\hline
\end{tabular}

${ }^{a}$ Data available for newborns who underwent the examination

${ }^{b}$ Some newborns had more than one CSF alteration, blood count alteration and clinical manifestation

and fifty-six (97.2\%) newborns had a physical examination recorded in their medical files and 199 (43.6\%) showed signs and symptoms of CS (Table 1).

Of the 469 newborns included in this analysis, only 210 (44.8\%) were treated with a nationally-recommended scheme. Of the 47 children who should have received a single dose of benzathine penicillin, 7 (14.9\%) received this treatment (Fig. 1) and 40 (85.1\%) were hospitalized for 10 days and treated with other intravenous regimens: 12 (30.0\%) ceftriaxone, 7 (17.5\%) procaine penicillin and 21 $(52.5 \%)$ received different multi-drug treatment regimens using ceftriaxone combined with penicillin procaine and/ or crystalline.

As alternative therapeutic options, ceftriaxone was used in $65(13.8 \%)$ newborns, Cefazolin in $15(3.2 \%)$ and a combination of more than one drug in 179 (38.2\%) (Table 2).

Multi-drug treatment regimens were used to treat 179 (38.2\%) newborns. A majority, 159 (88.8\%), received crystalline penicillin as the starting drug for treatment. Each combination presented corresponds to a 10-day treatment schedule (Table 3). 


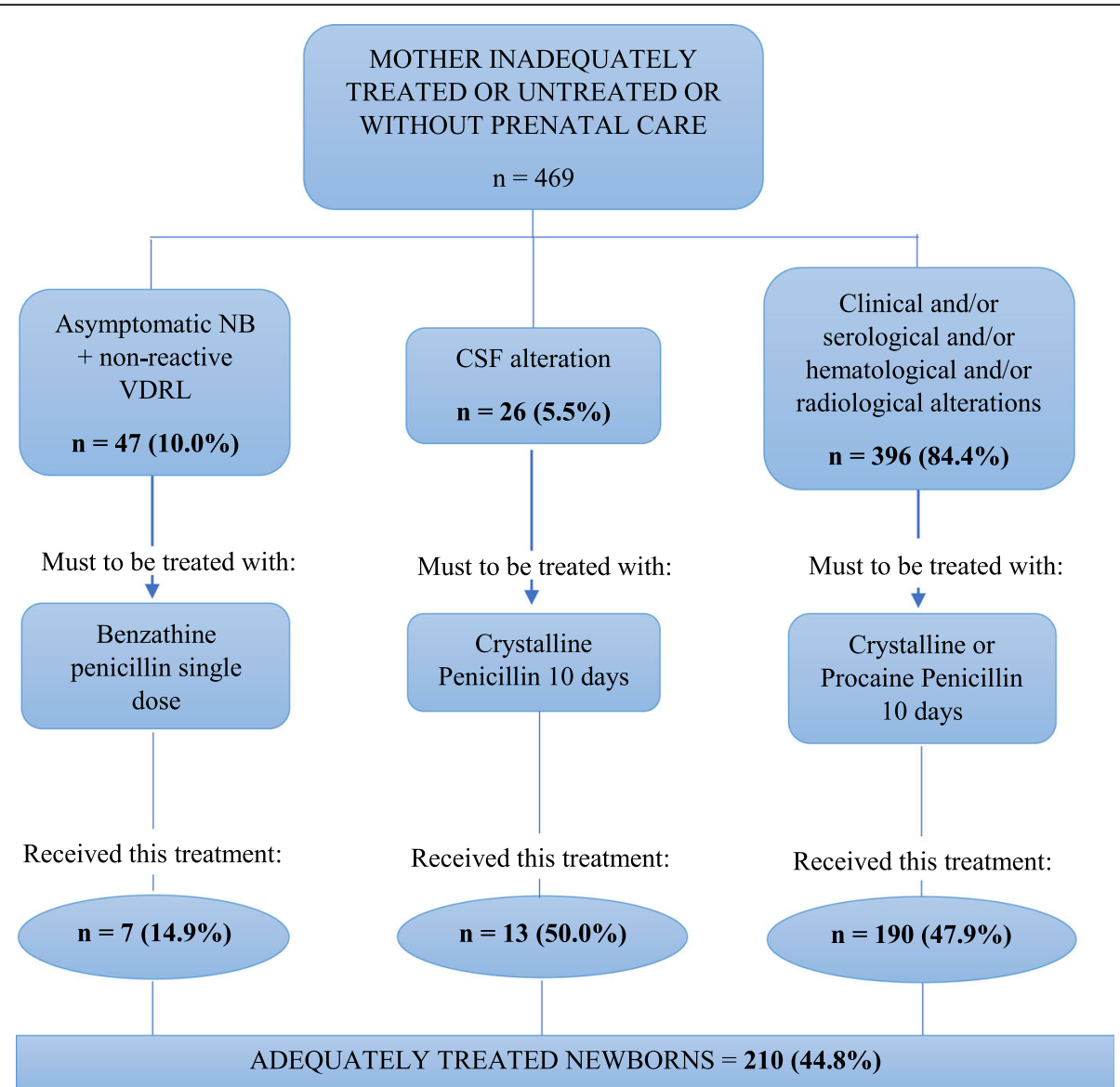

Fig. 1 Algorithm for adequate treatment to of newborns (NB) reported with CS. Fortaleza, Ceará, 2015. Source: adapted from: Ministry of Health (BR). Clinical Protocol and Therapeutic Guidelines for Integral Care to People with Sexually Transmitted Infections. Brasilia: Ministry of Health; 2015

Table 2 Treatments administered to CS during the penicillin shortage period. Fortaleza, Ceará. 2015. N = 469

\begin{tabular}{lll}
\hline Newborns' treatment & Number & Percent \\
\hline Standard scheme & & \\
Aqueous Crystalline Penicillin G 10 days & 187 & 39.9 \\
Procaine Penicillin G 10 days & 16 & 3.4 \\
$\quad$ Benzathine Penicillin G single dose & 7 & 1.5 \\
Total & $\mathbf{2 1 0}$ & $\mathbf{4 4 . 8}$ \\
Other schemes & & \\
$\quad$ Ceftriaxone 10 days & 65 & 13.8 \\
$\quad \begin{array}{l}\text { Cefazolin 10 days } \\
\text { Combination of more than one drug } \\
\text { (Crystalline Penicillin, Procaine Penicillin, }\end{array}$ & 15 & 3.2 \\
$\quad$ Benzathine Penicillin, Ceftriaxone, & 179 & 38.2 \\
$\quad \begin{array}{l}\text { Cephalothin) } \\
\text { Total }\end{array}$ & $\mathbf{2 5 9}$ & $\mathbf{5 5 . 2}$ \\
\hline
\end{tabular}

Infants with serum VDRL titers $\geq 1: 16(p=0.021)$, who had some clinical manifestation at birth $(p=0.003)$, who were born premature $(p<0.001)$, with low birth weight (0.010), with jaundice level requiring phototherapy $(p=$ $0.019)$ and with hepatomegaly $(p=0.045)$ were more likely to be treated with a nationally-recommended penicillin-based regimen (Table 4).

\section{Discussion}

Even in the face of a shortage of penicillin, all newborns reported with CS in Fortaleza during 2015 received some type of treatment. In the setting of limited or no availability of penicillin and unknown effectiveness of other medications used, professionals treated more than half of the newborns with other therapeutic schemes.

Prolonged hospitalizations and excessive use of antibiotics were identified for the vast majority of the newborns of this study who should have received a single dose of benzathine penicillin, making them susceptible to developing adverse reactions, hospital acquired infections, and other complications of hospitalization [10, 11]. Unnecessary hospitalizations 
Table 3 Other treatment schemes administered to CS combining drugs. Fortaleza, Ceará, 2015. N=179

\begin{tabular}{llll}
\hline Initial drug & Complementary drug (s) & Number & Percent \\
\hline Crystalline Penicillin & + Procaine Penicillin & 134 & 74.9 \\
& + Procaine Penicillin + Crystalline Penicillin & 6 & 3.3 \\
& + Benzathine Penicillin & 8 & 4.5 \\
& + Ceftriaxone & 3 & 1.7 \\
& + Procaine Penicillin + Benzathine & 2 & 1.1 \\
& + Ceftriaxone + Procaine Penicillin & 4 & 2.2 \\
Ceftriaxone & + Cephalothin + Procaine Penicillin & 2 & 1.1 \\
& + Procaine Penicillin & 17 & 3.5 \\
\hline
\end{tabular}

also compromised the scarce neonatal beds and increase the costs for the health system.

Unlike other studies $[12,13]$ carried out in Brazil during periods when penicillin was available, we identified a high proportion of CS cases treated according to the nationally-recommended standard therapy. During 2012 and 2013, prior to the penicillin shortages, Fortaleza had 612 and 663 live births reported with CS and 90,9\% and $92,6 \%$ respectively were treated with $\mathrm{MOH}$ - recommended regimens composed of crystalline, procaine or benzathine penicillin. Of the remainder of cases $8.4 \%$ (2012) and 6.8\% (2013) had no treatment reported. Only 4 cases in 2012 and 5 cases in 2013 were treated with non $\mathrm{MoH}$-recommended treatment regimens (Unpublished data provided by Fortaleza Health Secretary) compared with $210(44.7 \%)$ in 2015.

The $\mathrm{MoH}$ information note describing alternative treatment for CS was published in October 2015, about a year after the shortages began in Fortaleza. This note recommended the use of ceftriaxone for infants with CS in the event of unavailability of penicillin [6]. Therefore, for children born in the period prior to the publication of this note, the choice of treatment was at the discretion of the professionals and the drugs available in the services. This may explain some findings of this study, such as the use of cefazolin and the combination of different drugs.

Although the aim of this study is to evaluate the treatments offered to children reported with CS, it is noteworthy the proportion that did not undergo all the tests necessary for adequate clinical diagnosis. Health authority commitment to ensure access to and availability of adequate testing is essential, to guide appropriate treatment.

In view of the penicillin crisis, neonatologists may have tried to ration the few doses available in the services and prioritize these doses for use in infants with readily apparent clinical and laboratory abnormalities (serum VDRL titers $\geq 1: 16$, clinical manifestations at birth, preterm birth, low birth weight, jaundice consistent with need for phototherapy and hepatomegaly), demonstrated by the greater use of standard regimens among these infants. In turn, infants with abnormal CSF, long bone radiography and abnormal blood count findings were not more likely to receive a standard regimen. Though this seems contradictory to provider rationing of penicillin for severe CS cases, these exams are complex procedures within these facilities possibly resulting in delays in access to the results. Physicians may have chosen to treat infants with standard regimens who had obvious clinical manifestations or changes in other tests that were more immediately available.

There are several limitations to this study which demonstrate the missed opportunity to more robustly evaluate the outcomes of treatment regimens among pregnant women with syphilis and infants with congenital syphilis during this period of penicillin shortages. First, as some medical records could not be located, to maximize collection of available data, the authors reviewed data from different data sources including CS case notification forms in addition to medical records. Second, large amounts of data were missing and clinical parameters and test results were not evaluated consistently or were not available for all newborns, thus comparative analyses were limited. It should be noted that no other publications were identified in the peerreviewed literature whereby data on the use of alternative treatment regimens among newborns with CS were evaluated during a period of penicillin shortages. This made it impossible to compare the results to those of similar cases and settings. Finally, the diagnosis of CS is complex. In order to prevent the possibility of underdiagnosis and to minimize the risk of sequelae in children, WHO, CDC (Centers for Disease Control and Prevention), and Brazil define CS based on criteria that includes the syphilis treatment status of the mother $[8,14,15]$ which may include newborns without the infection.

Although the majority of newborns reported with CS were born without obvious clinical signs, it is possible that they may present early and/or late manifestations of CS if the treatment given was inadequate [16-19]. There 
Table 4 Alterations identified at birth in newborns reported with CS by treatment scheme, Fortaleza, Ceará, 2015

\begin{tabular}{|c|c|c|c|c|c|}
\hline \multirow[t]{3}{*}{ Variables } & \multicolumn{4}{|c|}{ Newborn Treatment } & \multirow[t]{3}{*}{$p$ value } \\
\hline & \multicolumn{2}{|c|}{ Standard scheme ${ }^{\mathrm{a}}$} & \multicolumn{2}{|c|}{ Other schemes } & \\
\hline & $\mathrm{n}$ & $\%$ & $\mathbf{n}$ & $\%$ & \\
\hline Serum VDRL result $(n=467)$ & & & & & 0.501 \\
\hline Reactive & 168 & 45.8 & 199 & 54.2 & \\
\hline Non-reactive & 42 & 42.0 & 58 & 58.0 & \\
\hline VDRL titration $(n=367)$ & & & & & 0.021 \\
\hline$\leq 1: 8$ & 136 & 43.3 & 178 & 56.7 & \\
\hline$\geq 1: 16$ & 32 & 60.4 & 21 & 39.6 & \\
\hline CSF alteration $(n=292)$ & & & & & 0.174 \\
\hline Yes & 13 & 50.0 & 13 & 50.0 & \\
\hline No & 97 & 36.5 & 169 & 63.5 & \\
\hline Long bone radiography alteration $(n=139)$ & & & & & $1.000^{\mathrm{b}}$ \\
\hline Yes & 3 & 30.0 & 7 & 70.0 & \\
\hline No & 46 & 35.7 & 83 & 64.3 & \\
\hline Blood count alteration $(n=362)$ & & & & & 0.155 \\
\hline Yes & 61 & 38.4 & 98 & 61.6 & \\
\hline No & 93 & 45.8 & 110 & 54.2 & \\
\hline Showed clinical manifestation at birth $(n=456)$ & & & & & 0.003 \\
\hline Yes & 105 & 52.8 & 94 & 47.2 & \\
\hline No & 100 & 38.9 & 157 & 61.1 & \\
\hline Preterm birth $(n=469)$ & & & & & $<0.001$ \\
\hline Yes & 43 & 66.2 & 22 & 33.8 & \\
\hline No & 168 & 41.6 & 236 & 58.4 & \\
\hline Low birth weight $(n=469)$ & & & & & 0.010 \\
\hline Yes & 50 & 57.5 & 37 & 42.5 & \\
\hline No & 161 & 42.1 & 221 & 57.9 & \\
\hline Jaundice with phototherapy $(n=454)$ & & & & & 0.019 \\
\hline Yes & 63 & 54.3 & 53 & 45.7 & \\
\hline No & 141 & 41.7 & 197 & 58.3 & \\
\hline Hepatomegaly $(n=456)$ & & & & & 0.045 \\
\hline Yes & 10 & 71.4 & 4 & 28.6 & \\
\hline No & 196 & 44.3 & 246 & 55.7 & \\
\hline Splenomegaly $(n=456)$ & & & & & $0.477^{b}$ \\
\hline Yes & 5 & 62.5 & 3 & 37.5 & \\
\hline No & 201 & 44.9 & 247 & 55.1 & \\
\hline Skin lesions $(n=456)$ & & & & & $0.353^{b}$ \\
\hline Yes & 6 & 60.0 & 4 & 40.0 & \\
\hline No & 195 & 44.3 & 245 & 55.7 & \\
\hline
\end{tabular}

a Considered when using any of the MoH-recommended treatment schemes: 1) aqueous crystalline penicillin G 50,000 IU/kg/dose, intravenously, every $12 \mathrm{~h}$ (in the first 7 days of life) and every $8 \mathrm{~h}$ (after 7 days of life), for 10 days; 2) procaine penicillin $\mathrm{G} 50,000 \mathrm{IU} / \mathrm{kg}$, single daily dose, intramuscularly for 10 days; 3 ) benzathine penicillin $\mathrm{G}$, a single dose of $50,000 \mathrm{IU} / \mathrm{kg}$ intramuscularly

${ }^{\mathrm{b}}$ Fisher's Exact test

is ongoing concern related to the follow-up of newborns reported with CS in Brazil during the period of 20142016 who received other treatment regimens for which clinical efficacy data are not available. It is expected that these infants received outpatient follow-up and assessment for the need for retreatment when penicillin was available once again [6]. Findings from this analysis were presented to health managers in the city of Fortaleza in 
2019 with the aim to reinforce the importance of performing an active search for children who may not have received adequate follow-up. Data from pediatric followup were not collected for this analysis but will be evaluated as part of future study.

The efficacy and clinical outcomes following use of alternative treatments provided to newborns with CS are not known. For this reason, comprehensive monitoring of these children is essential to assess their health status in the medium and long terms, as well as the need for possible retreatment [6]. Review of clinical follow-up of these infants will be considered for further study. Considering the possibility of recurrence of the shortage of penicillin [20], research that evaluates efficacy of alternative drugs for the treatment syphilis in pregnant women and newborns is essential.

\section{Conclusion}

These results demonstrate that in 2015, during the penicillin shortage, in Fortaleza, the proportion of newborns reported with CS who were adequately treated was low. Different therapeutic schemes were defined and administered based on their availability, including drugs that are not part of the $\mathrm{MoH}$ protocols. The data in this study warn of the need for clinical monitoring of these children who were treated as newborns with alternative, non-evidence-based treatment regimens for CS in order to detect and treat complications from possible inadequate treatment and to identify and evaluate alternative maternal and CS treatment regimens in advance of future penicillin shortages.

\section{Abbreviations}

CDC: Centers for Disease Control and Prevention; CS: Congenital Syphilis; CSF: Cerebrospinal fluid; MoH: Ministry of Health; NB: Newborns; SUS: Unified Health System (Sistema Único de Saúde); VDRL: Venereal Disease Research Laboratory; WHO: World Health Organization

\section{Acknowledgements}

Fortaleza Health Secretary for providing the unpublished CS datas. The author AFBR would like to thank FATENE (Faculdade Terra Nordeste) for granting a scholarship to carry out the research.

\section{Authors' contributions}

AFBR and MALA made substantial contributions to the study's conception and design. AFBR carried out data collection. AFBR, MALA, MMT, EOK e NJNB analyzed the data, prepared the first draft of the manuscript and were involved in revising it critically for important intellectual content. All authors read and approved the final manuscript.

\section{Funding}

Not applicable.

\section{Availability of data and materials}

The datasets generated and/or analyzed during the current study are not publicly available as they will still be further analyzed for other publications.

\section{Declarations}

\section{Ethics approval and consent to participate}

The study was approved by the Research Ethics Review Committees of the University of Fortaleza under No. 2,110,189, Universidade Federal do Ceará Maternidade Escola Assis Chateaubriand under No. 2,144,999, Hospital Geral de Fortaleza under No. 2,132,678 and Hospital Geral Dr. César Cals under No. $2,175,720$. These ethics review committees waived the need for consent as this is a retrospective survey using secondary data from medical records, which does not interfere with the care received by the patient. In addition, there are no physical and/or biological risks for the patient since the study is purely observational. The confidentiality of the personal identification of patients is guaranteed by the main researcher and by the techniques of data collection and storage: patients will be identified only through initials and registration numbers that serve only to validate the individuality of the information. The Loyal Depositary Term was used to authorize the collection of secondary data, assuming the responsibility of handling these data.

\section{Consent for publication}

Not applicable.

\section{Competing interests}

The authors declare that they have no competing interests.

\section{Author details}

'University of Fortaleza-UNIFOR, Av. Washington Soares, 1321, Edson Queiroz, Fortaleza, Ceará CEP 60.811-905, Brazil. ${ }^{2}$ World Health Organization, Department of Sexual Reproductive Health and Research, Geneva, Switzerland. ${ }^{3}$ US Centers for Disease Control and Prevention, Division of Sexually Transmitted Disease Prevention, Atlanta, GA, USA.

Received: 15 July 2020 Accepted: 21 March 2021

Published online: 08 April 2021

\section{References}

1. Korenromp EL, Rowley J, Alonso M, Brito de Mello M, Wijesooriya NS, Mahiané SG, et al. Global burden of maternal and congenital syphilis and associated adverse birth outcomes - estimates for 2016 and progress since 2012. PLOS One. 2019;14(2):e0211720.

2. Organización Panamericana de la Salud. Eliminación de la transmisión maternoinfantil del VIH y la sífilis en las Américas. Actualización 2016. Washington, DC: OPS; 2017.

3. Ministry of Health (BR). Boletim Epidemiológico Sifilis [Epidemiological Bulletin Syphilis]. Brasilia: Ministry of Health; 2019.

4. World Health Organization. Global guidance on criteria and processes for validation: elimination of mother-to-child transmission of HIV and syphilis. 2nd ed. Geneva: World Health Organization; 2017.

5. Nurse-Findlay S, Taylor MM, Savage M, Mello MB, Saliyou S, Lavayen M, et al. Supply, demand, and shortages of Benzathine penicillin for treatment of syphilis: a market assessment. PLoS Med. 2017;14(12):e1002473. https://doi. org/10.1371/journal.pmed.1002473.

6. Ministry of Health (BR). Nota Informativa Conjunta. N¹09/2015/GAB/SVS/MS, GAB/SCTIE/MS. Orienta a respeito da priorização da penicilina benzatina para sífilis em gestantes e penicilina cristalina para sífilis congênita no país e alternativas para o tratamento da sífilis [lt advises on the prioritization of benzathine penicillin for syphilis in pregnant women and crystalline penicillin for congenital syphilis in the country and alternatives for the treatment of syphilis]. Brasília: Ministry of Health; 2015.

7. Secretaria da Saúde do Estado do Ceará. Boletim Epidemiológico de Sífilis [Epidemiological Bulletin of Syphilis]. Fortaleza: Secretaria da Saúde do Estado do Ceará; 2019. https://www.saude.ce.gov.br/wp-content/uploads/ sites/9/2018/06/boletim_sifilis_2019.pdf. Accessed 15 Jan 2020.

8. Ministry of Health (BR). Clinical Protocol and Therapeutic Guidelines for Integral Care to People with Sexually Transmitted Infections. Brasilia: Ministry of Health; 2015.

9. Lee GR, Bithell TC, Foerster J, Athens JW, Lukens JN. Wintrobe Hematologia Clínica. 9th edition: Manole; 1998.

10. Patel SJ, Saiman L. Antibiotic resistance in neonatal intensive care unit pathogens: mechanisms, clinical impact, and prevention including antibiotic stewardship. Clin Perinatol. 2010;37(3):547-63. https://doi.org/10.1016/..clp.2 010.06.004. 
11. Ministry of Health (BR). Pediatria: prevenção e controle de infecção hospitalar [Pediatrics Manual - Hospital Infection Prevention and Control]. Brasilia: Ministry of Health; 2006.

12. Kawaguchi IAL, Magalhães DMS, Calderon IMP, Dias A. Follow-up of congenital syphilis in children treated at birth. Com Ciências Saúde. 2014; 24(3):221-30.

13. Magalhães DMS, Kawaguchi IAL, Dias A, Calderon IMP. Sífilis materna e congênita: ainda um desafio [maternal and congenital syphilis: a persistent challenge]. Cad Saúde Pública. 2013;29(6):1109-20. https://doi.org/10.1590/ S0102-311X2013000600008.

14. World Health Organization. Guidelines for the treatment of Treponema pallidum (syphilis). Geneva: World Health Organization; 2016.

15. Centers for Disease Control and Prevention. 2015 Sexually Transmitted Diseases Treatment Guidelines. https://www.cdc.gov/std/tg2015/congenital. $\mathrm{htm}$. Accessed 26 Jan 2021.

16. Feliz MC, Medeiros ARP, Rossoni AM, Tahnus T, Pereira AMVB, Rodrigues C. Adherence to the follow-up of the newborn exposed to syphilis and factors associated with loss to follow-up. Rev bras epidemiol. 2016;19(4):727-39. https://doi.org/10.1590/1980-5497201600040004.

17. Lafetá KRG, Martelli Júnior H, Silveira MF, Paranaíba LMR. Maternal and congenital syphilis, underreported and difficult to control. Rev. Bras. Epidemiol. 2016;19(1):63-74. https://doi.org/10.1590/1980-5497201600010006.

18. Lago EG, Vaccari A, Fiori RM. Clinical features and follow-up of congenital syphilis. Sex Transm Dis. 2013;40(2):85-94. https://doi.org/10.1097/OLQ. Ob013e31827bd688.

19. Cavalcante ANM, Araújo MAL, Nobre MA, Almeida RLF. Fatores associados ao seguimento não adequado de crianças com sífilis congênita. Rev Saúde Pública. 2019;53:95. https://doi.org/10.11606/s1518-8787.2019053001284.

20. Taylor MM, Nurse-Findlay S, Zhang X, Hedman L, Kamb ML, Broutet N, et al. Estimating benzathine penicillin need for the treatment of pregnant women diagnosed with syphilis during antenatal care in high-morbidity countries. PLoS One. 2016;11(7):e0159483. https://doi.org/10.1371/journal. pone. 0159483

\section{Publisher's Note}

Springer Nature remains neutral with regard to jurisdictional claims in published maps and institutional affiliations.

Ready to submit your research? Choose BMC and benefit from:

- fast, convenient online submission

- thorough peer review by experienced researchers in your field

- rapid publication on acceptance

- support for research data, including large and complex data types

- gold Open Access which fosters wider collaboration and increased citations

- maximum visibility for your research: over $100 \mathrm{M}$ website views per year

At $\mathrm{BMC}$, research is always in progress.

Learn more biomedcentral.com/submissions 